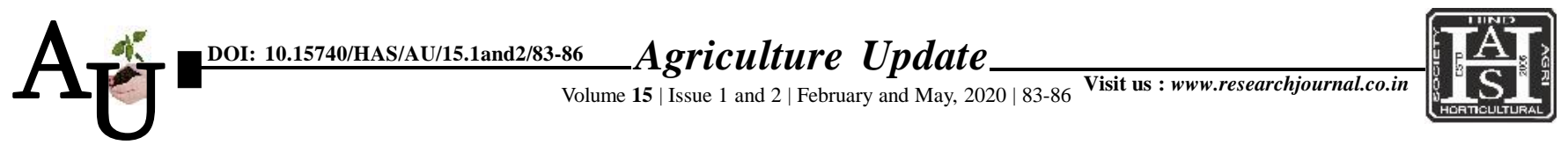

ISSN-0973-1520

\title{
Research article: Attitude toward homestead technologies among RAWE (IAHS) students
}

\author{
Anju Kapri, Jyoti Rani and Seema Rani
}

Article Chronicle: Received :

21.03.2020;

Revised :

11.04.2020;

Accepted :

20.04.2020

Key Words:

Homestead,

Technologies,

Respondents,

Develop, Adopting
SUMMARY : Various technologies have been developed by the scientists working in College of Home Sciences operational under agricultural universities for alleviating drudgery, increasing efficiency and technological empowerment of rural women in the areas like health, nutrition, sanitation, child rearing, resource management, clothing and textile and entrepreneurship. It is very much necessary to disseminate these technologies and make them to adopt by rural women. Present study was conducted in CCSHAU, Hisar and data was collected from total of 50 students who were already completed their IAHS Programmes of I.C. College of Home Science. Questionnaire were prepared regarding attitude was used to collect the data. Results revealed that majority $(56.00 \%)$ of the respondents were agreed with the IAHS has helped to get familiar with rural people and 61.00 per cent of the respondents were strongly agreed with the IAHS has helped to understand village situations. Result also showed that cent per cent respondents were strongly agreed with the statement 'there is a need to develop more technologies that are purely meant for women' and 'the University should develop more low-cost household technologies'. By seeing other people living nearby their places adopting new thing, rural women should try to start these things for better life and to improve the condition of their living.

How to cite this article : Kapri, Anju, Rani, Jyoti and Rani, Seema (2020). Attitude toward homestead technologies among RAWE (IAHS) students. Agric. Update, 15(1 and 2): 83-86; DOI : 10.15740/HAS/AU/15.1and2/83-86. Copyright@ 2020: Hind Agri-Horticultural Society.
Author for correspondence :

\section{Anju Kapri}

Department of

Extension Education and

Communication

Management, C.C.S.

Haryana Agricultural

University, Hisar

(Haryana) India

Email: anukap707@

gmail.com

See end of the article for authors' affiliations 